Башкирцев Всеволод Геннадьевич, магистрант, Ангарский государственный технический университет, e-mail: bashkircevsevolod@mail.ru

Раскулова Татьяна Валентиновна, д.Х.н., заведующий кафедрой ХTT, Ангарский государственный технический университет, ВНЕДРЕНИЕ ПРОЦЕССА ПЕРЕРАБОТКИ ОТХОДОВ ПОЛИОЛЕФИНОВ В ГРАНУЛИРОВАННЫЙ ПРОДУКТ НА АО «АЗП»

\title{
Bashkirtsev V.G., Raskulova T.V. WASTE RECYCLING POLYOLEFINS PROCESS IMPLEMENTATION IN A GRANULATED PRODUCT AT JSC «ANGARSK POLYMER PLANT»
}

\begin{abstract}
Аннотация. Рассмотрена возможность внедрения технологической линии по переработке отходов производства полиолефинов в гранулированный высокомаржинальный продукт на площадке $A O$ «Ангарский завод полимеров».

Ключевые слова: полиолефины, линия гранулирования, вторичное сырьё.

Annotation. The possibility of introducing a production line for processing polyolefin production wastes into a granular high-margin product at the site of JSC «Angarsk polymer plant» was considered.
\end{abstract}

Key words: polyolefins, granulation line, recycled materials.

Полиолефины (полиэтилен, полипропилен, полибутилен) представляют собой один из наиболее распространенных видов синтетических полимеров. В России в 2018 г. объём производства всех видов полиэтилена составил 1,8 млн тонн [1]. Такое распространение полиолефины приобрели благодаря ряду ценных свойств: высокой эластичности, отличным диэлектрическим показателям, низкой теплопроводности, высокой химической и термической устойчивости, механической прочности, а также относительно низкой стоимости. Наряду с достоинствами, изделия из полиолефинов имеют ряд недостатков, важнейшим из которых является сложность их биологического и химического разложения. Сроки, необходимые для полного разложения изделий из полиолефинов до простых веществ (углекислого газа и воды) составляют от 100 до 400 лет [2].

В процессе производства и дальнейшего использования полимерных изделий образуется большое количество отходов. Рост производства полимеров неуклонно ведет к росту их доли в составе бытовых и промышленных отходов, а также делает необходимыми разработку и применение процессов их утилизации. Так как процессы термической ликвидации пластиковых отходов сопряжены с образованием больших количеств токсичных соединений [3], наибольший интерес представляет их вторичная переработка в конечные изделия [4].

Цель работы - оценка возможности внедрения на площадке АО «АЗП» технологической линии по переработке пластика.

Принципиальная схема технологической линии по переработке вторичного полиолефинового сырья приведена на рисунке 1. Вторичное полиолефино- 
вое сырье проходит стадии измельчения и промывки, осушку в центрифуге и поступает в промежуточный накопитель. Из накопителя чистая сухая дробленка подается на стадию переработки путем экструзии расплава и дальнейшего гранулирования. При гранулировании возможно внесение в расплав красителей и модифицирующих добавок, меняющих свойства и вид получаемой продукции относительно входного сырья.

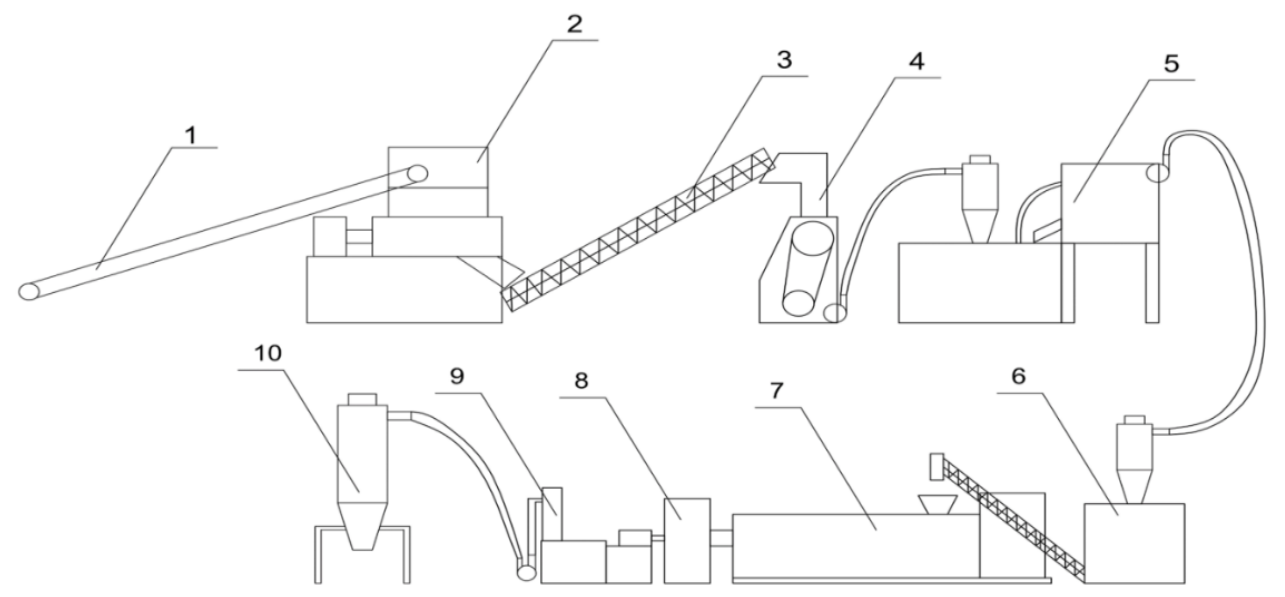

Рисунок 1 - Принципиальная схема технологической линии по переработке вторичного полиолефинового сырья в гранулированный продукт: 1 - ленточный транспортер; 2 - шредер; 3 - шнек для выгрузки; 4 - дробилка; 5 - мойка; 6 - шнековый дозатор; 7 - экструдер; 8 - фильтр; 9 - водокольцевая резка; 10 - циклон

Как показали предварительные экономические расчеты, стоимость предлагаемой технологической линии равна 19290 тыс. рублей, при этом срок окупаемости затрат составит 3,4 года. Стоимость конечного продукта превышает операционные затраты на производство, поэтому гранулированный продукт на выходе высокомаржинальный. Для внедрения данной линии в $\mathrm{AO}$ «АЗП» имеются все возможности: свободные помещения, логистика, коммерческие предложения для закупки вторичного сырья, отходы полиэтилена собственного производства, энергоснабжение, лаборатория для подтверждения качества продукта. В настоящее время достигнута договоренность министерства экономического развития и министерства природных ресурсов, министерства экологии Иркутской области о сотрудничестве и поддержке данного проекта.

\section{ЛИТЕРАТУРА}

1. Рынок полиолесинов в России [Электронный ресурс // https://article.unipack.ru/77170/ (дата обращения 02.03.2020).

2. Родионов А.И., Клушин В.Н., Систер В.Г. Технологические процессы экологической безопасности. Калуга: Издательство Н. Бочкаревой, 2000. 800 с.

3. Быстров Г.А., Гальперин В.М., Титов Б.П. Обезвреживание и утилизация отходов в производстве пластмасс. Л.: Химия, 1982. 264 с.

4. Вторичное использование полимерных материалов / Под редакцией Е.Г. Любешкиной. М.: Химия, 1985. 280 с. 